\title{
Amino Acids in Brewer's Yeast Involved in Heavy Metal Biosorption from Waste Water
}

\author{
Andreea STĂNILĂ $\breve{1}^{1}$ Tania MIHĂESCU² \\ ${ }^{1}$ Faculty of Food Science and Technology, University of Agricultural Sciences and Veterinary Medicine, \\ 400372, 3-5 Manastur St., Cluj-Napoca, Romania \\ ${ }^{2}$ Faculty of Agriculture, University of Agricultural Sciences and Veterinary Medicine, 400372, 3-5 \\ Manastur St., Cluj-Napoca, Romania \\ * corresponding author: tania.mihaescu@usamvcluj.ro
}

Bulletin USAMV series Agriculture 72(1)/2015

Print ISSN 1843-5246; Electronic ISSN 1843-5386

DOI 10.15835/buasvmcn-agr: 11172

\begin{abstract}
Yeasts of genera Saccharomyces are efficient biosorbents for heavy metal ions. The aim of this study was to identify if the free amino acids present in brewer yeast are involved in metal biosorption due to their capacity to coordinate metal ions.

As biosorbent was used non-living brewer's yeast type Saccharomices cerevisae at $0.5 \%$ yeast dose. Copper, lead and zinc solution of $1 \mathrm{mg} / \mathrm{L}$ concentrations were prepared using their salts. The experiments were conducted at three $\mathrm{pH}$ level $(3.5 ; 5 ; 6)$. The amino acids were identified by HPLC chromatography and FT-IR spectroscopy. The experiments were conducted by mixing metals solution with yeast and shaken at a constant speed of $120 \mathrm{rpm}$ at $20^{\circ} \mathrm{C}$ for 120 minute. The samples were centrifugated at $2500 \mathrm{rpm}$ for 15 minute and the pellet were analysed for amino acids identification. The amino acids extraction from pellets were performed using two solvent types: $\mathrm{HCl} 0.05 \mathrm{M} /$ ethanol and $\mathrm{HCl} 0.05 \mathrm{M} /$ water. The HPLC analysis was performed using a C-18 column and a mixture of $\mathrm{K}_{2} \mathrm{HPO}_{4} 50 \mathrm{mM} /$ acetonitrile solution as mobile phase in gradient conditions. The FT-IR spectra of samples extracts were recorded with Shimadzu IR-Prestige spectrophotometer.

The amino acids identified by HPLC method were Glu, Arg, Ala, Gly, Lys, Hys, Met, Threo and their profile differs according with extraction solvent used and the $\mathrm{pH}$ of the pellets. Best results were obtained with $\mathrm{HCl}$ / water system and the appropriate $\mathrm{pH}$ for metal biosorption was 6. In the FT-IR spectra information about metal coordination were obtained by comparing the IR amino acids frequencies from control extract with the samples. The presence of shifted absorption band demonstrated the involvement of amino acids by their $\mathrm{NH}_{2}$ and $\mathrm{COOH}$ groups in metals coordination.
\end{abstract}

Keywords: amino acids, biosorption, brewer yeast, heavy metals

\section{INTRODUCTION}

Biosorption can be defined as the selective sequestering of metal soluble species that result in the immobilization of the metals by microbial cells. Biosorption is a process with some unique characteristics. It can effectively sequester dissolved metals from very dilute complex solutions with high efficiency. This makes biosorption an ideal candidate for the treatment of high volume low concentration complex wastewaters $[1,2]$.

The selective sequestering of metal soluble species that result in the immobilization of the metals by microbial cells is defined as biosorption. It refers to physicochemical mechanisms of inactive (i.e. non-metabolic) metal uptake by microbial biomass [3]. Metal sequestering by different parts of the cell can occur via various processes: complexation, chelation, coordination, ion exchange, precipitation, reduction [4, 5]. Immobilization may be the result of more than one mechanism, for example, metal complexation may be followed by metal reduction or metal precipitation.

Metabolically active and inactive cells behave in different ways. Thus inactive microbial cells can 
only immobilize metals by biosorption, whereas active microbial cells may immobilize soluble metal species both by biosorption and by other mechanisms that are part of and/or are due to the microbial metabolism [6].

The cell wall is usually the first cellular structure that comes in contact with the soluble metal species in the extracellular environment, if the possibility of interaction and retention of metal species by extracellular excretions produced by some microbial cells is excluded [7].

Fungal cell walls are typically composed of the polysaccharides chitin and cellulose, and the cell walls of algae and plants are composed mainly of the polysaccharide cellulose [8].

Proteins, amino acids, polysaccharides and nucleic acids $[9,10]$ are the major polymer groups ubiquitous in the living world, being found in all members of the animal, plant, and microorganism groups.

These biopolymers, constituents of the cell wall and the other parts of the cell possess functional groups that have a significant potential for metal binding [11].

Metal uptake by non-living cells is mainly a passive biosorption and consist in an adsorption of metal ions to the cells surface by interactions between metal and functional groups displayed on the surface of the cells [12].

Brewer's yeast is made from a one-celled fungus called Saccharomyces cerevisiae and is used to make beer. It also can be grown to make nutritional supplements. Brewer's yeast is a rich source of minerals, especially chromium, an essential trace mineral that helps the body maintain normal blood sugar levels, selenium, amino acids, protein and the B-complex vitamins $[13,14]$.

The yeast biomass has been successfully used as biosorbent for removal of $\mathrm{Ag}, \mathrm{Au}, \mathrm{Cd}, \mathrm{Co}, \mathrm{Cr}, \mathrm{Cu}$, $\mathrm{Ni}, \mathrm{Pb}, \mathrm{U}$, Th and $\mathrm{Zn}$ from aqueous solution. Yeasts of genera Saccharomyces, Candida, Pichia are efficient biosorbents for heavy metal ions. Most of yeasts can bond a wide range of metal ions or be strictly specific in respect of only one metal ion. A number of literatures have proved that $S$. cerevisiae can remove toxic metals, recover precious metals and clean radionuclides from aqueous solutions to various extents $[15,16,17,18,19,20]$.

\section{MATERIALS AND METHODS}

Saccharomices cerevisae biomass was supplied as a lyophilized by-product from industrial ethanol production. Prior use as a biosorbent, the biomass was pretreated in order to remove fine particles and to displace any metals already bound to the sorption sites. The waste biomass as washed with deionized water by stirring followed by centrifugation at $3000 \mathrm{rpm}$ for 20 minutes. The supernatant was discarded and the pellet was reslurried in deionized water. The procedure was repeated for three times until the supernantant was clear.

Metals solution were prepared using the mixture of their salts $\mathrm{CuSO}_{4} \cdot 5 \mathrm{H}_{2} \mathrm{O}, \mathrm{PbNO}_{3} \cdot 2 \mathrm{H}_{2} \mathrm{O}$, $\mathrm{ZnSO}_{4}$ of analytical reagent grade. The concentrations of metals ions established were $1 \mathrm{mg} / \mathrm{L}$ for $\mathrm{Cu}^{2+}, \mathrm{Zn}^{2+}, \mathrm{Pb}^{2+}$ and were obtained by dissolving the appropriate salts in deionized water.

Experimental procedure:

Metal ion binding experiments were performed by incubation of $25 \mathrm{mg}$ biomass (dry weight) with $50 \mathrm{ml}$ mixture of metals ionscontaining solution in 125-ml Erlenmeyer flask on an orbital rotary shaker at $120 \mathrm{rpm}$ for 120 minutes. The experiment was conducted at three pH values: 3.5; 5 and 6 and were established by adjusting it with $\mathrm{HCl} 0.1 \mathrm{M}$ or $\mathrm{NaOH} 0.1 \mathrm{M}$ solutions.

In order to identify the free amino acids from biomass by HPLC chromatography and FT-IR spectroscopy the samples were centrifugated at $2500 \mathrm{rpm}$ for 15 minutes, the supernatant was discarded and the pellets were analysed.

The free amino acids were extracted from the pellets using two types of solutions: $\mathrm{HCl} 0,05 \mathrm{M} /$ ethanol $80 \%(\mathrm{v} / \mathrm{v}) 1 / 1$ and $\mathrm{HCl}$ 0,05M/deionized water $(\mathrm{v} / \mathrm{v}) 1 / 1$.

The extracts obtained were injected into the HPLC system. The HPLC analyses were carried out on the Agilent 1200 system with a UV-Vis detector, using a reverse phase Ultra Aqueous C18 column (150 x $4.6 \mathrm{~mm}), 5 \mu \mathrm{m}$. A gradient mobile phase was used: $\mathrm{K}_{2} \mathrm{HPO}_{4} 50 \mathrm{mM} / \mathrm{ACN}$, where acetonitrile concentration range between $5 \%$ and $50 \%$ in a 20 minutes intervals with a flow rate of $0.5 \mathrm{~mL} /$ minute. All chromatograms were monitored at $240 \mathrm{~nm}$.

The HPLC peaks were identified by using parallel HPLC runs with amino acids standard solutions at $1 \mathrm{mg} / \mathrm{ml}$ concentration in $\mathrm{HCl} 0,05 \mathrm{M} /$ ethanol $1 / 1$ solution [21]. 
FT-IR analysis was performed using the same extracts prepared for HPLC and also biomass powder. For this analysis it was used a Shimadzu IR Prestige 21 device with a Horizontal Attenuated Total Reflectance Accessory for FTIR Spectrometers and the domain recorded for amino acids acid was $700-4500 \mathrm{~cm}^{-1}$.

\section{RESULTS AND DISCUSSIONS}

HPLC Chromatography

The absorption mechanisms of metals are different and depends on cellular metabolism. In non-living brewer yeast this mechanism is one of physical-chemical interaction between metal ions and some functional groups, especially amino and carboxyl.

The aim of this study was to establish the amino acids from brewer yeast involvement in metal ions biosorption, as it is known that amino and carboxyl groups could be responsible for complexation depending on $\mathrm{pH}$ intervals and metal:ligand ratio. In the HPLC chromatograms these involvement could be observed by changing the absorption intensities between amino acids from brewer yeast control and brewer yeast charged with metal ions by biosorption.

The standard solutions of amino acids used for analysis were selected according with the literature data regarding the presence of these compounds in brewer yeast [21]. The main amino acids present in brewer yeast and identified were: Glutamic acid (Glu), Lysine (lys), Arginine (Arg), Methionine (Met), Alanine (Ala), Glycine (Gly), Threonine (Threo) and Hystidine (Hys).

The separation and identification of amino acids were performed on brewer yeast uncharged with metal ions (control) and brewer yeast charged with metal ions after their biosorption at different $\mathrm{pH}$ values. The solvents extraction used were $\mathrm{HCl} 0,05 \mathrm{M} /$ ethanol $80 \%$ solution and $\mathrm{HCl}$ $0,05 \mathrm{M} /$ deionized water solution. The results are presented in Table 1 and Figures 1 and 2.

Tab.1. Amino acids identified in brewer yeast uncharged with metal ions using two different extraction solvents

\begin{tabular}{ccccc}
\hline Nr. & Amino acid & $\begin{array}{c}\mathrm{t}_{\mathrm{R}} \text { (min.) Standards } \\
\text { mixture solution }\end{array}$ & $\begin{array}{c}\mathrm{t}_{\mathrm{R}} \text { (min) Control } \\
\text { (water extraction) }\end{array}$ & $\begin{array}{c}\mathrm{t}_{\mathrm{R}} \text { (min.)Control } \\
\text { (ethanol extraction) }\end{array}$ \\
\hline 1 & Glu & 3.25 & 3.3 & 3.13 \\
\hline 2 & Lys & 3.77 & 3.72 & 3.70 \\
\hline 3 & Arg & 4.02 & 3.97 & 3.95 \\
\hline 4 & Met & 4.74 & 4.82 & - \\
\hline 5 & Ala & 5.61 & 5.53 & 8.23 \\
\hline 6 & Gly+Threo & 8.09 & 8.26 & 12.36 \\
\hline 7 & Hys & 12.06 & 12.62 & \\
\hline
\end{tabular}

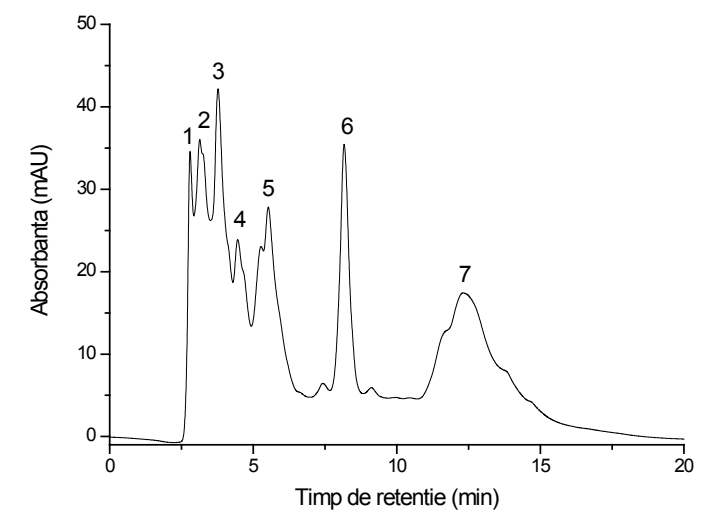

Fig.1. HPLC chromatogram of amino acids from brewer yeast uncharged with metal ions ( $\mathrm{HCl} 0.05 \mathrm{M} /$ water extraction)

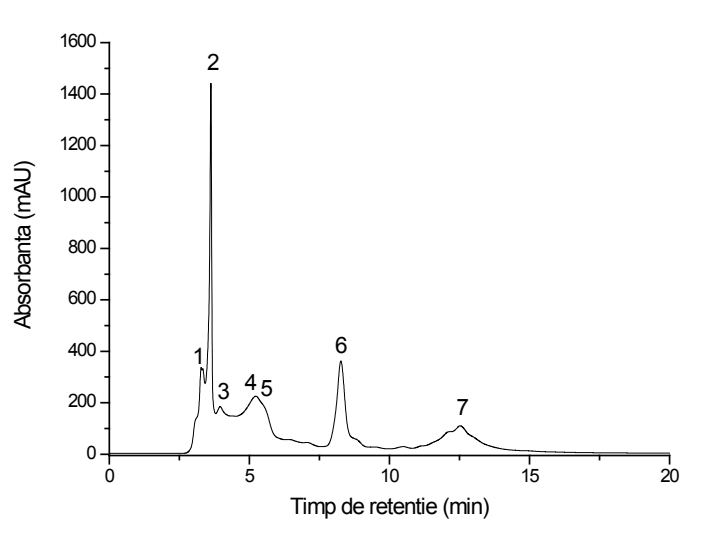

Fig. 2. HPLC chromatogram of amino acids from brewer yeast uncharged with metal ions ( $\mathrm{HCl} 0.05 \mathrm{M} /$ ethanol extraction) 
As it can be observed (Fig.1 and Fig.2) in brewer yeast sample where it was used ethanol for amino acids extraction the peak assigned to methionine overlap the next peak corresponding to alanine due to an inefficient separation. There are also some unidentified peaks in both chromatograms.

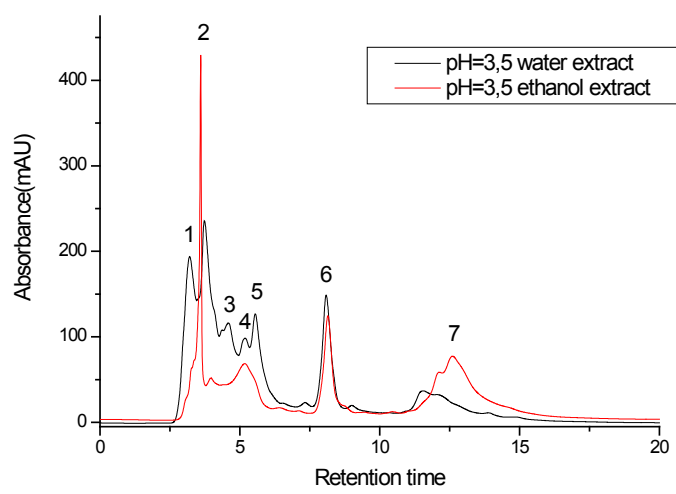

a)
The next figures show the differences between solvents extraction at different values of $\mathrm{pH}$.

The better amino acids separation were obtained using acidulated water extraction at all three different $\mathrm{pH}$ value. The profile of chromatograms are different between control brewer yeast and samples charged with metal

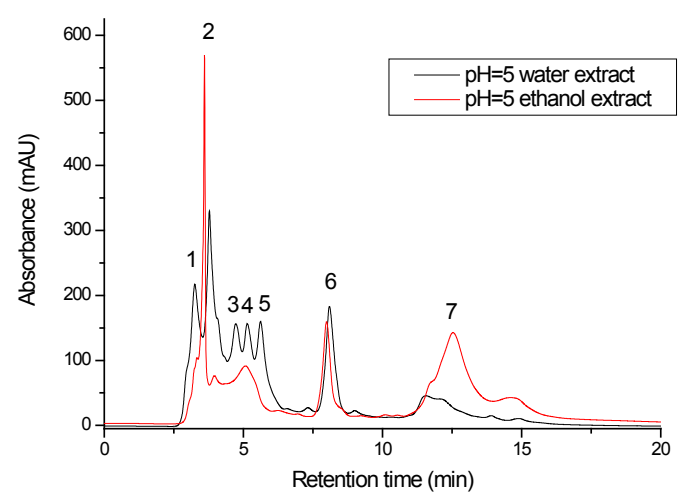

b)

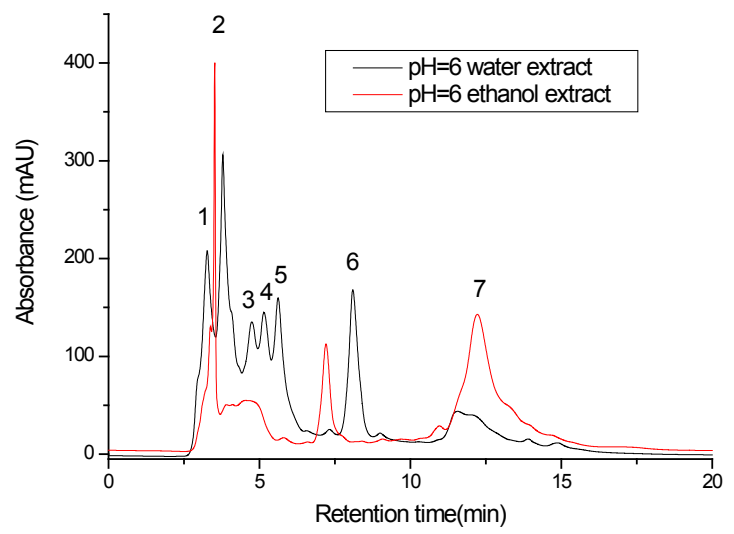

c)

Fig.3.a), b), c) HPLC chromatograms of amino acids from brewer yeast charged with metal ions after extraction at different $\mathrm{pH}$ value and different solvent

Tab. 2. Amino acids identified in brewer yeast charged with metal ions at different $\mathrm{pH}$ values using acidulated water as solvent extraction

\begin{tabular}{cccccc}
\hline Nr. & Amino acid & $\begin{array}{c}\mathrm{t}_{\mathrm{R}}(\text { min.) } \\
\text { Control }\end{array}$ & $\begin{array}{c}\mathrm{t}_{\mathrm{R}}(\mathrm{min} .) \\
\text { Sample } \\
\mathrm{pH}=3.5\end{array}$ & $\begin{array}{c}\mathrm{t}_{\mathrm{R}} \text { (min.) } \\
\text { Sample } \\
\mathrm{pH}=5\end{array}$ & $\begin{array}{c}\mathrm{t}_{\mathrm{R}}(\mathrm{min} .) \\
\text { Sample } \\
\mathrm{pH}=6\end{array}$ \\
\hline 1 & Glu & 3.3 & 3.20 & 3.25 & 3.27 \\
\hline 2 & Lys & 3.72 & 3.73 & 3.77 & 3.76 \\
\hline 3 & Arg & 3.97 & 3.96 & 3.96 & 3.90 \\
\hline 4 & Met & 4.82 & 4.80 & 4.83 & 5.88 \\
\hline 5 & Ala & 5.63 & 5.55 & 5.60 & 8.10 \\
\hline 6 & Gly+Threo & 8.26 & 8.14 & 8.09 & - \\
\hline 7 & Hys & 12.62 & - & - & - \\
\hline
\end{tabular}


ions due to the absorption of copper, zinc and lead after incubation. It is supposed that amino acids from brewer yeast has the capacity to coordinate these metal ions and the complexes resulted have different retention times and absorbance intensity than free amino acids as it can be seen in the next tables.

From the data above it can be presumed that $\mathrm{pH}=6$ is appropriate for metals biosorption, thus some amino acids ( Arg, Met, Ala, Gly, Threo) are involved in metal coordination and have changed their intensity absorption capacity. Amino acids content could be affected by autolysis and fermentation conditions like time, temperature, $\mathrm{pH}$, moisture content [22].

FT-IR Spectroscopy

In order to identify the free amino acids and their possible complexes with $\mathrm{Cu}, \mathrm{Zn}$ and $\mathrm{Pb}$ the usual method is to assign the absorption IR bands

Tab. 3. Amino acids identified in brewer yeast charged with metal ions at different $\mathrm{pH}$ values using $\mathrm{HCl} /$ ethanol as solvent extraction

\begin{tabular}{cccccc}
\hline Nr. & Amino acid & $\begin{array}{c}\mathrm{t}_{\mathrm{R}} \text { (min.) } \\
\text { Control }\end{array}$ & $\begin{array}{c}\mathrm{t}_{\mathrm{R}}(\min .) \\
\text { Sample } \\
\mathrm{pH}=3.5\end{array}$ & $\begin{array}{c}\mathrm{t}_{\mathrm{R}}(\mathrm{min} .) \\
\text { Sample } \\
\mathrm{pH}=5\end{array}$ & $\begin{array}{c}\mathrm{t}_{\mathrm{R}}(\mathrm{min} .) \\
\text { Sample } \\
\mathrm{pH}=6\end{array}$ \\
\hline 1 & Glu & 3.13 & - & 3.33 & 3.37 \\
\hline 2 & Lys & 3.70 & 3.60 & 3.60 & 3.62 \\
\hline 3 & Arg & 3.95 & 3.96 & 3.99 & - \\
\hline 4 & Met & - & 4.94 & 4.97 & - \\
\hline 5 & Ala & 5.23 & 5.17 & 5.09 & - \\
\hline 6 & Gly+Threo & 8.16 & 8.14 & 7.99 & 12.2 \\
\hline 7 & Hys & 12.36 & 12.01 & 12.06 & \\
\hline
\end{tabular}

Tab. 4. FT-IR spectral data $\left(\mathrm{cm}^{-1}\right)$

\begin{tabular}{ccccccccc}
\hline Band & $\begin{array}{c}\text { Control } \\
\text { powder }\end{array}$ & $\begin{array}{c}\text { Powder } \\
\text { pH 3.5 }\end{array}$ & $\begin{array}{c}\text { Powder } \\
\text { pH 5 }\end{array}$ & $\begin{array}{c}\text { Powder } \\
\text { pH 6 }\end{array}$ & $\begin{array}{c}\text { Control } \\
\text { extract }\end{array}$ & $\begin{array}{c}\text { Extract } \\
\text { pH 3,5 }\end{array}$ & $\begin{array}{c}\text { Extract } \\
\text { pH 5 }\end{array}$ & $\begin{array}{c}\text { Extract } \\
\text { pH 6 }\end{array}$ \\
\hline$\delta(\mathrm{N}-\mathrm{H})$ & 1563 & 1555 & 1566 & 1571 & 1551 & 1547 & 1560 & 1566 \\
\hline$v(\mathrm{C}=0)$ & 1610 & 1603 & 1622 & 1631 & 1648 & 1640 & 1655 & 1659 \\
\hline
\end{tabular}

The comparative FT-IR spectra are presented in figures 4 and 5.
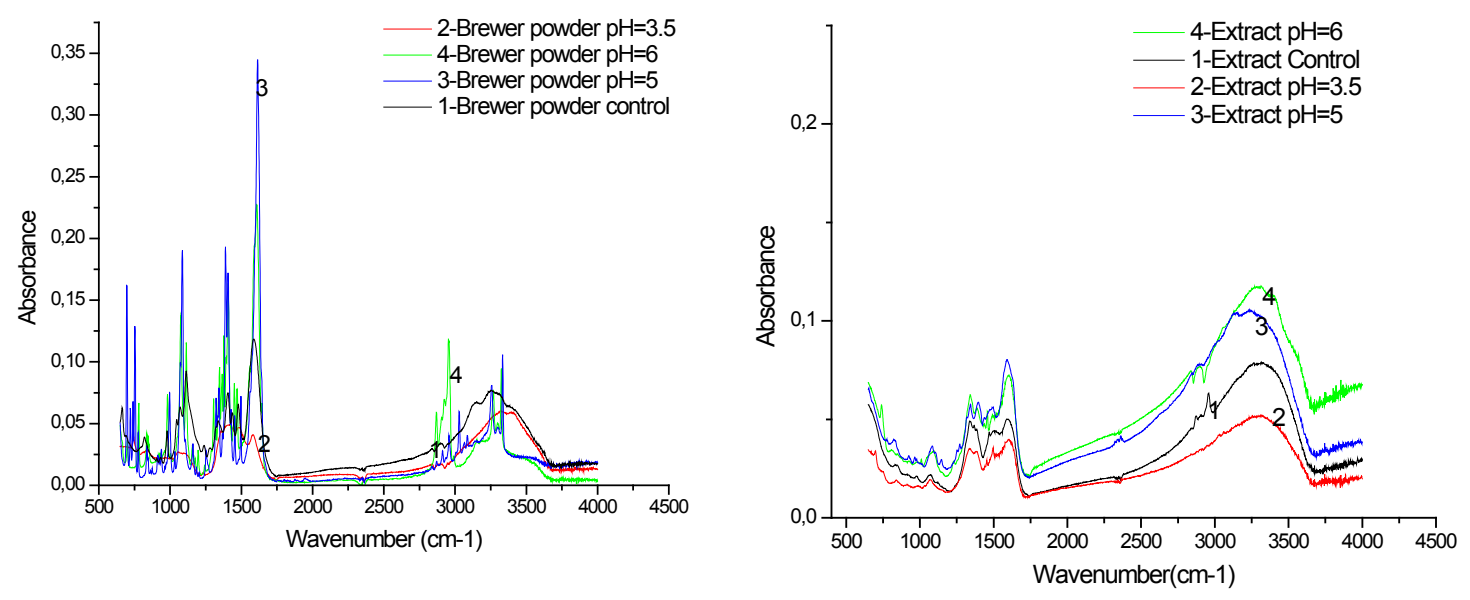

Fig. 4. The FT-IR spectra of amino acids from Fig. 5. The FT-IR spectra of amino acids extracted brewer yeast powder in acidulated water from brewer yeast powder 
of the main groups: amino $\left(-\mathrm{NH}_{2}\right)$ and carboxyl $(-\mathrm{COOH})$.

The aim of this experiment was to compare the IR absorption bands specific for amino acids from brewer yeast uncharged with metal ions (control) with the IR absorption bands of the samples at different $\mathrm{pH}$ values. If these bands appear to be shifted toward higher frequencies in the samples spectra comparing with the control, it can be concluded that these groups are involved in the complex formation with metal ions [23].

In the FT-IR spectra of amino acids molecules must be assigned the next frequencies:

$\delta(\mathrm{N}-\mathrm{H})$ asymmetric and symmetric bending vibration

$v(\mathrm{C}=0)$ asymmetric and symmetric stretching vibrations.

The next table summarize the results from the

FT-IR spectra recorded.

According to the data presented it can be concluded that amino acids from brewer yeast could be involved in metal biosorption due to the shifting and splitting of the amino and carboxyl groups vibrations.

The $v(\mathrm{C}=0)$ stretching vibration is shifted toward higher frequencies in the spectra of samples at pH 5 and 6 which involves the carboxylic group in covalent bonding to the metal ions [24].

The involvement of $-\mathrm{NH}_{2}$ group to the metal bonding was assigned to shifting of the $\delta(\mathrm{N}-\mathrm{H})$ asymmetric and symmetric bending vibration to the higher frequencies in the complexes spectra of samples at $\mathrm{pH} 5$ and 6 , which lead us to the conclusion that these $\mathrm{pH}$ values are appropriate for metal coordination.

\section{CONCLUSION}

This study represent a first step in elucidation of the absorption mechanism of metal ions from aqueous solution by brewer yeast. Thus, the preliminary results lead to the conclusion that free amino acids, above other constituents from yeast, could be involved in metal biosorption. This process is strongly dependent on experimental conditions, especially on pH level, as it is known that each metal ions have characteristic $\mathrm{pH}$ limits for coordination with different organic ligands.

For this study it could be concluded that for $\mathrm{Cu}$, $\mathrm{Zn}$ and $\mathrm{Pb}$, the optimal $\mathrm{pH}$ interval for complexation is between five and six. Above this value appear the possibility of $\mathrm{Pb}$ salts precipitation.
Acknowledgement. This work was supported by a grant of the Romanian Ministry of Education, CNCSIS - UEFISCDI, PN-II-RU-PD-2012-3 - 0055", nr. $47 / 30.04 .2013$

\section{REFERENCES}

1. Ahalya N, Ramachandra TV, Kanamadi RD (2003). Biosorption of heavy metals. Research Journal of Chemistry and Environment 7(4):71-79.

2. Alluri HK, Ronda SR, Setalluri VS (2007). Biosorption: an ecofriendly alternative for heavy metal removal. African Journal of Biotechnology 6(25):2924-2931.

3. Dakiky M, Khamis M, Manassra A, Mereb M (2002). Selective adsorption of chromium (VI) in industrial wastewater using low-cost abundantly available adsorbents. Adv. Environ. Res. 6:533-540.

4. Das N, Vimala R, Karthika P (2008). Biosorption of heavy metals - An overview. Indian Journal of Biotechnology 7:159-169.

5. Gadd GM (1993). Interactions of fungi with toxic metals. Phytologist 124:25-60

6. Kapoor A, Viraraghavan T (1997). Fungi as biosorbents. Biosorbents for metal ions. In: Wase J, Forster C, editors: London, UK: CRC Press:67-86.

7. Lekkas C, Stewart G, Hill AE, Taidi B, Hodgson J (2002). Elucidation of the Role of Nitrogenous Wont Compounds in Yeast Fermentation. J. Instit. Brew.113(1):3-8.

8. Mahmood T, Malik SA, Hussain ST (2010). Biosorption of Metals. Bioresources 5(2):1244-1256

9. Malik A (2004). Metal bioremediation through growing cells. Environ Int. 30:261-78.

10. Marcu A, Stanilă A, Rusu D, Rusu M, Cozar O, David L (2007). Spectroscopic studies of copper (II) complexes with some amino acids. Journal of Optoelectronics and Advanced Materials 9(3):741-46.

11. Ozer A, Ozer D (2003). Comparative study of the biosorption of $\mathrm{Pb}(\mathrm{II}), \mathrm{Ni}(\mathrm{II})$ and $\mathrm{Cr}(\mathrm{VI})$ ions onto $\mathrm{S}$. cerevisiae: determination of biosorption heats. J. Hazard. Mater.100:219-29.

12. Paknikar KM, Pethkar AV, Puranik PR (2003). Bioremediation of metalliferous Wastes and products using Inactivated Microbial Biomass. Indian J. Biotechnol. 2:426-443.

13. Podgorskii VS, Kasatkina TP, Lozovaia OG (2004). Yeastsbiosorbents of heavy metals. Mikrobiol. Z 66:91-103.

14. Romera E, Gonzalez F, Ballester A, Blazquez ML, Munoz JA (2006). Biosorption with Algae: A Statistical Review. J. Crit. Rev. Biotechnol. 26:223-235.

15. Socrates G (2001). Infrared and Raman Characteristic Group Frequencies: Tables and Charts. Third edition, Wiley, Chichester:171-173.

16. Stanilă A, Marcu A, Rusu D, Rusu M, Marcu G, David L (2007). Spectroscopic studies of copper (II) complexes with amino acids. Journal of Molecular Structure 36468:834-836.

17. Tálos K, Páger C, TonkS, MajdikC, Kocsis B, Kilár F, Pernyeszi T (2009). Cadmium biosorption on native Saccharomyces 
cerevisiae cells in aqueous suspension. Acta Universitatis Sapientiae, Agriculture and Environment 1:20-30

18. Thiele B, Fullner K, Stein N, Arnd MO, Kuhn A, Hofman D (2008). Analysis of amino acids without derivatization in barley extract by LC-MS-MS. Anal. Bioanal. Chem. 391:2663-2672

19. Tsezos M (2001). Biosorption of metals - The experience accumulated and the outlook for technology development. Hydrometallurgy 59:241-3.

20. Volesky B (2001). Detoxification of metal-bearing effluents: biosorption for the next century. Hydrometallurgy 59:203-16.

21. Volesky B, Holan ZR (1995). Biosorption of heavy metals. Biotechnol Prog. 11:235-250
22. Wang JL, Chen C (2006). Biosorption of heavy metals by Saccharomyces cerevisiae: a review. Biotechnol Advances 24:427-51.

23. Wang JL, Chen C (2009). Biosorbents for heavy metal removal and their future. Biotechnology Advances 27:195-226

24. Wang JL, Han YJ, Qjan Y (2000). Progress in metal biosorption by microorganisms. Microbiology 27:449452.

25. Zouboulis AI, Rousou EG, Matis KA, Hancock IC (1999). Removal of toxic metals from aqueous mixtures, Part 1: Biosorption. J. Chem Technol Biot 74:429-36. 